\title{
Getting into the Minds of Pairs of Liars and Truth Tellers: An Examination of Their Strategies
}

\author{
Aldert Vrij ${ }^{*}$, , Samantha Mann ${ }^{1}$, Sharon Leal ${ }^{1}$ and Pär Anders Granhag ${ }^{2}$ \\ ${ }^{I}$ University of Portsmouth, Psychology Department, King Henry Building, King Henry 1 Street, Portsmouth, PO1 2DY, UK \\ ${ }^{2}$ University of Gothenburg, Sweden
}

\begin{abstract}
We examined the strategies used by 20 pairs of liars and 20 pairs of truth tellers when they were given the opportunity to prepare themselves for an interview in which they would be questioned about their whereabouts during a given period of time. More lying than truth telling pairs prepared themselves for the interviews. The truth tellers and liars who did prepare themselves used different verbal strategies but the same nonverbal strategies. Regarding verbal strategies, truth tellers were predominantly concerned with telling everything they could remember. In contrast, liars thought of answers they could give to possible questions but also decided to be vague so that they would not contradict each other. Regarding nonverbal strategies, both truth tellers and liars tried to suppress nervous behaviours. These findings explain why truth tellers are typically more detailed than liars but also why liars are typically equally consistent as truth tellers, at least when answering questions they have anticipated. Implications for interview techniques to detect deceit are discussed.
\end{abstract}

Keywords: liars' and truth tellers verbal ane nonverbal strategies, lie detection.

In their attempts to detect lies it will benefit criminal investigators to obtain insight into how truth tellers and liars prepare themselves for their interviews (Granhag \& Hartwig, 2008). This insight could predict what truth tellers and liars say and how they behave during an interview, and criminal investigators could use this insight to develop effective theory-based lie detection protocols. Given the importance, it is surprising that truth tellers' and liars' strategies to appear credible in an interview have been understudied for a long time (DePaulo, Lindsay, Malone, Muhlenbruck, Charlton, \& Cooper, 2003). However, DePaulo et al.'s (2003) plea for research into this area has resulted in several studies (Colwell, Hiscock-Anisman, Memon, Woods, \& Michlik, 2006; Granhag \& Strömwall, 2002; Granhag, Strömwall, \& Hartwig, 2007; Hartwig, Granhag, \& Strömwall, 2007; Strömwall, Granhag, \& Landström, 2007; Strömwall, Hartwig, \& Granhag, 2006).

The present strategies study differed from the previous studies in two important ways. First, previous studies concentrated on the strategies developed by individual truth tellers and liars whereas we focused on pairs of truth tellers and pairs of liars. We believe that this reflects an important aspect of real life, because criminals often work in groups or networks rather than alone. Second, after being interviewed, we asked the truth tellers and liars whether there were awkward moments during the interview that could have jeopardised their credibility. The answers are valuable to criminal investigators, as it gives insight into what interviewees believe went wrong during their interviews. Interviewees may well concentrate on these aspects the next

*Address correspondence to this author at the University of Portsmouth, Psychology Department, King Henry Building, King Henry 1 Street, Portsmouth, PO1 2DY, UK; Tel: +44 239284 8484; Fax: +44 239284 6300; E-mail: aldert.vrij@port.ac.uk time their credibility is challenged. This information thus predicts future strategies.

In theory, truth tellers and liars face the same task during the interview: They both need to convince an interviewer that they are innocent (Granhag \& Hartwig, 2008; Hartwig, Granhag, Strömwall, Wolf, Vrij, Roos af Hjelmsater, 2008). However, when pairs of truth tellers and pairs of liars are given the opportunity to prepare themselves for an interview, they are likely to react differently. Pairs of liars will realise that it is crucial to plan and discuss together the facts of their fabricated story so they "get their stories straight" (Granhag, Strömwall, \& Jonsson, 2003). If pairs of liars do not do this they run the risk of each providing statements that are inconsistent with one another, thereby raising doubts about their truthfulness. By comparison, pairs of truth tellers are less likely to prepare for the interview, because they believe that the truth shines through anyway (illusion of transparency, Gilovich, Savitsky, \& Medvec, 1998). As such, whilst truth tellers may also think that it is important that their two statements are consistent, they may think that this will happen naturally without having to prepare. We therefore predicted that pairs of liars would be more likely to prepare themselves for the interview than pairs of truth tellers (Hypothesis 1).

Those pairs of truth tellers and liars who do develop a joint strategy to appear credible are likely to develop different verbal strategies to achieve this aim. Truth tellers can simply disclose in detail during the interview everything that happened. In contrast, liars cannot do this but have to fabricate a story. They need to make sure that the information they give sounds plausible, but does not contradict facts that the interviewer knows or may find out. In case two liars are interviewed about the same event, as happened in the present experiment, they should also make sure they provide the same information and do not contradict 
each other. Therefore, truth tellers are likely to report that they discussed as a pair that they would say in the interview what had happened, and that they ran through the event together to remind each other of the details of the event (Hypothesis 2). In contrast, liars are likely to report that they, as a pair, had agreed on which fabricated story to tell during the interview to make sure that their stories would match one another. Liars further may have agreed not to disclose too much detail, because the more detail they provided, the higher the chance that they would contradict one another or say something the interviewer knows to be untrue (Hypothesis 3).

The pairs of truth tellers and liars who develop a joint strategy to appear credible will develop similar nonverbal strategies to achieve this aim. People overwhelmingly believe that displaying nervous behaviour appears suspicious, in particular gaze aversion, fidgeting or other sorts of movements (Strömwall, Granhag, \& Hartwig, 2004; The Global Deception Team, 2006; Vrij, 2008a; Vrij, Akehurst, \& Knight, 2006). There is no theoretical reason why truth tellers and liars will have different views on this. Therefore, both truth tellers and liars are likely to report that they discussed amongst themselves that they would try to suppress displaying nervous behaviours such as gaze aversion, fidgeting or other movements (Hypothesis 4).

After the interview we asked truth tellers and liars whether they had experienced awkward moments during the interview. Liars' tendency to take their credibility less for granted than truth tellers will make them more conscious of themselves during the interview and probably more aware of imperfections during such interviews. In addition, because lying is often cognitively more demanding than truth telling (Vrij, Fisher, Mann, \& Leal, 2006, 2008, 2009), liars probably would think that they made more mistakes than truth tellers, as a more difficult task is likely to result in more errors. We thus expected that liars have experienced more awkward moments and thought they have said or done more things wrong in the interviews than truth tellers (Hypothesis $6)$.

If asked what they have said wrong, truth tellers and liars are likely to provide different answers. People typically believe that providing accounts that lack detail, mentioning that they cannot remember something, or contradicting each other, will sound suspicious (Strömwall, Granhag, \& Hartwig, 2004; The Global Deception Team, 2006; Vrij, 2008a; Vrij, Akehurst, \& Knight, 2006). For truth tellers the issue of contradicting each other should not play a role as they have no reasons to believe that they would contradict each other. Truth tellers will therefore mainly be concerned that they did not provide enough detail, and that they admitted lack of memory (Hypothesis 7). In contrast, it will be predominantly on liars' minds that they should not contradict each other, as they probably will think that their alibi falls apart if they do so. Liars will therefore mainly be concerned that they contradicted their partner (Hypothesis 8).

If asked what they have done wrong, truth tellers and liars are both likely to report the same thing: They will probably believe that they have shown nervous behaviours such as gaze aversion, fidgeting and other type of movements (Hypothesis 9).

\section{METHOD}

\section{Participants}

Eighty undergraduate students, 13 males and 67 females, participated. Their average age was $M=19.36(S D=2.29)$ years.

\section{Procedure}

The event was modified from Granhag et al. (2003), and reported in detail in Vrij, Leal, Granhag, Mann, Fisher, Hillman, \& Sperry (2009). Pairs of participants were recruited under the guise of a study about social interaction.

\section{Truth Tellers}

On arrival at the Psychology Department laboratory, each pair of truth tellers (20 pairs, 40 truth tellers in total) was told that the study would take place at Gunwharf, a shopping centre near the Psychology Department. An experimenter (Sharon) brought the pair to Gunwharf. On the way Sharon pretended to receive a text message saying that the experiment is running late. She therefore brought the pair of participants to one of three restaurants and told them that they can spend up to $£ 15$ on lunch (but no alcohol). Three research-assistant observers were already in the three designated restaurants to check that all pairs would have lunch and stay in the restaurant (all pairs did). After 45 minutes Sharon returned to the restaurant. The truth tellers were told that, as the study was running late, the format had changed slightly and that the study would be carried out in the Psychology Department.

When the participants returned to the Psychology Department laboratory, a second experimenter (Jackie) told each pair of truth tellers that they were both suspected of having committed a crime (taking two $£ 5$ notes out of a room) when they had lunch together and that in about 10 minutes they would be interviewed individually about their alibi. They were told that their task is to convince the interviewer that their alibi is true, having lunch together in Gunwharf. The interviewer did not know if the alibi was true but made a judgement at the end of the interview. To motivate the participants to perform well during the interview they were informed that if the interviewer believed the participant, they would be paid $£ 10$; in contrast, if she did not believe the participant, they would not receive any money, and may be asked to write a statement about their whereabouts during lunch-time instead. The pairs were then left alone together for 10 minutes. After 10 minutes each pair was taken to two different cubicles to fill out individually the pre-interview questionnaire. The questionnaire asked about the participant's gender and age, and whether he or she had discussed an interview strategy together with the other participant (yes/no). If they did not develop a strategy we asked them via an open-ended question why they did not do this. In case they did develop a strategy, we asked them via an open-ended question to describe it.

After completing the questionnaire each participant was taken individually into the interview room where they were interviewed. Questions were asked about the layout of the restaurant, the food they had consumed, and the conversations they had. After the interview the participants individually completed the post-interview questionnaire, 
which asked (i) how motivated they were to perform well during the interview (7-point Likert scale ranging from [1] very unmotivated to [7] very motivated); (ii) to estimate the likelihood of receiving $£ 10$ and having to write a statement (both on 7-point Likert scales ranging from [1] very unlikely to [7] very likely); and (iii) whether they had experienced any awkward moments during the interview (answers were given on a 7-point Likert scales ranging from [1] not at all to [7] plenty). This question was followed by two specific questions about whether there was something (1) they had said or (2) done during the interview that raised suspicion (answers were given on 7-point Likert scales ranging from [1] not at all to [7] definitely). Via two open-ended questions we asked the participants to list (1) the speech content and (2) nonverbal behaviours that they thought had raised suspicion. ${ }^{1}$ The answers to the open-ended questions are not statistically tested for two reasons. These qualitative answers are not really suitable for quantitative statistical testing. Moreover, for some questions too few participants provided answers to enable statistical testing.

\section{Liars}

At arrival in the Psychology Department laboratory, the second experimenter (Jackie) told each pair of liars (20 pairs, 40 liars in total) that two $£ 5$ notes were hidden in a purse in an empty room. Each pair was instructed to go together to the room, take the money out of the purse, share it and return. When they returned from taking the money, the pairs in the were told that they were suspected of having taken money out of a purse, that they would be interviewed individually in 10 minutes about this and that they had 10 minutes to fabricate an alibi about their whereabouts during the last 45 minutes. This alibi is that someone called Sharon took them as a pair to Gunwharf for an experiment, that the experiment was running late, and that they were therefore taken to a restaurant to have lunch together, paid for by the Department, and that Sharon returned after 45 minutes. They were then told that their task in the interview would be to convince the interviewer that they actually were in the restaurant as a pair. The interviewer would not know if the alibi is true but would make a judgement at the end of the interview. If the interviewer believes them, they would be paid £10, and could keep the money they took out of the wallet, but if she does not believe them, they would not receive the additional $£ 10$, and may be asked to write a statement about their whereabouts instead. The pairs were then left alone together for 10 minutes. After 10 minutes the pair of suspects were taken to two different cubicles to fill out the pre-interview questionnaire individually (see above). After completing the questionnaire each was taken separately into the interview room and were interviewed. After the interview the participants completed the post-interview questionnaire individually (see above). The participants were then debriefed, thanked and given $£ 10$ apiece. $^{2}$

\footnotetext{
${ }^{1}$ Participants did not know whether or not the interviewer had believed them when they completed the post-interview questionnaire.

${ }^{2}$ The condition reported in the text is the 'immediate' condition. In another condition, the participants (truth tellers and liars) were sent home after their lunch/stealing the money and asked to return one week later. This delay factor is not relevant for this article and no hypotheses about it were formulated. However, to precise the error term we included the Delay factor as factor in our statistical analyses.
}

\section{RESULTS}

\section{Motivation and Manipulation Checks}

The vast majority of participants $(78 \%)$ indicated that they were motivated to perform well during the interview (score of 5 or higher on the 7-point Likert scale). A 2 (Veracity) $\mathrm{X} 2$ (Delay) ANOVA revealed that the experimental manipulations had no effect on the motivation of the participants, all $F^{\prime} s<1.83$, all $p$ 's $>.19$ (grand mean score $(M=5.36, S D=1.41))$.

Two 2 (Veracity) X 2 (Delay) ANOVAs were conducted with the estimated likelihood of receiving $£ 10$ and having to write a statement as the dependent variables. These analyses revealed only main effects for Veracity $(£ 10: F(1,78)=$ $40.17, p<.01$, eta $^{2}=.35, d=1.44$; and Writing a statement: $F(1,78)=38.49, p<.01$, eta $\left.^{2}=.34, d=1.41\right)$. Truth tellers thought it more likely that they would receive the $£ 10$ incentive $(M=5.08, S D=1.1)$ than liars $(M=3.13, \mathrm{SD}=$ 1.6), whereas liars thought it more likely that they would have to write a statement $(M=5.08, S D=1.3)$ than truth tellers $(M=3.20, S D=1.4)$. In summary, participants reported to have been highly motivated to perform well during the interview, and the promise of an incentive and the threat of a punishment appeared realistic to them.

\section{Preparation}

A 2 (Veracity) X 2 (Delay) X 2 (Preparation $^{3}$ ) loglinear analysis was carried out to examine difference in preparation between liars and truth tellers, and between the delay and immediate conditions. The analysis revealed one effect, a significant Preparation $\mathrm{X}$ Veracity interaction effect, $Z=$ $1.83, p<.05$. Frequency scores revealed that, as predicted in Hypothesis 1 , more liars $(N=26,65 \%)$ than truth tellers $(N$ $=12,30 \%$ ) reported that they had prepared an interview strategy, $X^{2}(1, N=80)=9.83, \mathrm{p}<.01$.

Most truth tellers reported that they had run through everything that had happened at the restaurant (Table 1). This supports Hypothesis 2. Some truth tellers reported that they had discussed that they would mention the travel to and from the restaurant, or had made sure that they knew the times (duration) of events. In terms of behaviour, some truth tellers had discussed that they would try to be relaxed, maintain eye contact and refrain from smiling. This supports Hypothesis 4.

Compared to truth tellers, liars had discussed different things. Their deliberations focused on discussing what to say and how to match their stories. They discussed specific details, such as the location and where they sat in the restaurant, what they would say that they had consumed at the restaurant, and the duration of events. In other words, they prepared answers to possible questions. Some liars $(N=$ 4) had decided to be vague. These findings support Hypothesis 3. In terms of behaviour, keeping their hands still was the most frequently mentioned joint strategy, which supports Hypothesis 4.

\footnotetext{
${ }^{3}$ Out of interest we included Preparation as a factor in the design to examine whether those who had prepared themselves before the interview experienced fewer awkward moments than those who did not prepare themselves.
} 
Table 1. Details of the Participants' Joint Interview Strategy

\begin{tabular}{|c|c|c|}
\hline & $\begin{array}{l}\text { Truth Tellers } \\
\qquad(\mathrm{N}=12)\end{array}$ & $\begin{array}{c}\text { Liars } \\
(\mathbf{N}=\mathbf{2 6})\end{array}$ \\
\hline \multicolumn{3}{|l|}{ Speech } \\
\hline Ran through what had happened & 9 & 0 \\
\hline Matching stories & 1 & 11 \\
\hline Discussed what to say (alibi) & 2 & 9 \\
\hline Travel to and from restaurant & 3 & 2 \\
\hline Food and drink & 0 & 8 \\
\hline Location and where we sat & 0 & 3 \\
\hline Conversations & 0 & 1 \\
\hline Times & 2 & 3 \\
\hline Being vague & 0 & 4 \\
\hline \multicolumn{3}{|l|}{ Behaviour } \\
\hline Relaxed & 2 & 3 \\
\hline Appear convincing & 0 & 1 \\
\hline Keep eye contact & 2 & 2 \\
\hline Keep hands still & 0 & 4 \\
\hline Don't smile & 1 & 0 \\
\hline Tone of voice & 0 & 2 \\
\hline Keep feet still & 0 & 1 \\
\hline
\end{tabular}

Table 2 presents the reasons for the 28 truth tellers and 14 liars not to prepare for their interviews. Most truth tellers indicated that they thought it was unnecessary to develop a strategy. Whilst some liars also thought it unnecessary to develop a strategy, most liars did not do so because they were uncertain about what questions would be asked during the interview.

\section{Post-Interview Questionnaire Results}

To examine differences in the participants' experiences during the interview, a 2 (Veracity) X 2 (Delay) $\mathrm{X} 2$ (Preparation) MANOVA was carried out with the variables listed in Table $\mathbf{3}$ as dependent variables. The MANOVA revealed a significant main effect for Veracity, $F(5,68)=$ 3.63, $p<.01$, eta ${ }^{2}=.21$. All other effects were not significant (all $F$ 's $<2.03$, all $p$ 's $>.13$ ).

Liars felt more than truth tellers that there were awkward moments during the interview, and that their speech and behaviour increased suspicion (Table 3). Liars could also think of more things they should have said or done in order to convince the interviewer than truth tellers. This supports Hypothesis 5.

Table 2. Reasons why Participants Did Not Develop a Joint Interview Strategy Before the Interview

\begin{tabular}{|l|c|c|}
\hline & $\begin{array}{c}\text { Truth Tellers } \\
(\mathbf{N}=\mathbf{2 8})\end{array}$ & $\begin{array}{c}\text { Liars } \\
(\mathbf{N}=\mathbf{1 4})\end{array}$ \\
\hline \hline Not needed & 22 & 4 \\
\hline Did not think about it & 3 & 3 \\
\hline No idea what could be asked/no time & 2 & 5 \\
\hline
\end{tabular}

Twenty-one truth tellers and 31 liars indicated which aspects of their speech they thought would have made the interviewer suspicious. Truth tellers were mainly concerned that telling the interviewer that they no longer remembered the conversations they had or the order in which these conversations occurred, made them look suspicious (Table 4). This supports Hypothesis 6. In contrast, liars primarily thought that their answers to the questions about the layout made them look suspicious. They were also concerned that they may have contradicted their partner, which supports Hypothesis 7.

Twenty-three truth tellers and 29 liars reported which of their behaviour they thought would have raised suspicion in the interviewer. Truth tellers thought that their fidgeting and other movements in particular would have evoked suspicion (Table 5). Liars mainly thought that their lack of eye contact, and their fidgeting and other movements would have made them look suspicious. All such behaviours indicate nervousness, supporting Hypothesis 8.

\section{DISCUSSION}

In the present experiment we examined the strategies of pairs of truth tellers and pairs of liars when they prepare for an interview in which their whereabouts during a given period of time would be discussed. After the interview, we examined whether they thought that there were any awkward moments during the interview that could have jeopardised

Table 3. Participants' Impressions of (i) Their Own Speech and (ii) Their Own Behaviour During the Interview as a Function of Veracity

\begin{tabular}{|c|c|c|c|c|c|c|c|c|}
\hline & \multicolumn{2}{|c|}{ Truth Tellers } & \multicolumn{2}{|c|}{ Liars } & \multirow{2}{*}{$\frac{F}{(1,76)}$} & \multirow{2}{*}{$\mathbf{p}$} & \multirow{2}{*}{ Eta $^{2}$} & \multirow{2}{*}{ d } \\
\hline & $\mathbf{M}$ & SD & $\mathbf{M}$ & SD & & & & \\
\hline Awkward moments & 3.25 & 1.7 & 4.68 & 1.6 & 14.97 & $* *$ & .17 & .87 \\
\hline Suspicious speech & 3.20 & 1.8 & 5.10 & 1.7 & 23.30 & $* *$ & .24 & 1.09 \\
\hline Suspicious behaviour & 3.45 & 1.8 & 4.70 & 1.6 & 10.09 & $* *$ & .12 & .74 \\
\hline What to say to be more convincing & 2.18 & 1.7 & 3.20 & 2.0 & 6.05 & $*$ & .07 & .55 \\
\hline How to behave to be more convincing & 2.45 & 1.8 & 3.40 & 2.1 & 4.85 & * & .06 & .49 \\
\hline
\end{tabular}


their credibility. Truth tellers were less inclined than liars to plan a strategy. Truth tellers believed it was unnecessary to do so, because they thought that it was not needed (see also Kassin, 2005). Liars typically take their credibility less for granted than truth tellers and were therefore more likely to prepare a strategy.

Table 4. Speech that May Have Sound Suspicious in the Interview

\begin{tabular}{|l|c|c|}
\hline & Truth Tellers (N = 21) & Liars (N = 31) \\
\hline \hline Too much/not enough detail & 3 & 3 \\
\hline Layout & 4 & 14 \\
\hline Conversations & 8 & 4 \\
\hline Sounded nervous/uncertain & 1 & 4 \\
\hline Contradictions with partner & 1 & 6 \\
\hline Contradictions with myself & 3 & 4 \\
\hline Contradicting facts & 0 & 3 \\
\hline Lack of memory & 2 & 1 \\
\hline
\end{tabular}

Table 5. Behaviour that May Have Appeared Suspicious in the Interview

\begin{tabular}{|l|c|c|}
\hline & $\begin{array}{c}\text { Truth Tellers } \\
(\mathbf{N}=\mathbf{2 3})\end{array}$ & $\begin{array}{c}\text { Liars } \\
(\mathbf{N}=\mathbf{2 9})\end{array}$ \\
\hline \hline Demeanour: Nervous/unsettled/forced relaxation & 1 & 6 \\
\hline Fidgeting & 12 & 9 \\
\hline Too many other movements & 7 & 6 \\
\hline Too many pauses & 4 & 5 \\
\hline Lack of eye contact & 3 & 10 \\
\hline Stutters/repetitions & 0 & 3 \\
\hline Closed/shifting body posture & 3 & 0 \\
\hline Nervous laughter & 0 & 2 \\
\hline Other (coughing, blushing/lip biting) & 2 & 5 \\
\hline
\end{tabular}

Truth tellers and liars who prepared a strategy used different verbal strategies. Truth tellers were mainly concerned with telling what had happened. Therefore, they ran with their partners through what had happened during the period of time that they would be questioned about. After the interview they were concerned that they had not provided enough details during the interview, thereby running the risk of not being believed. In contrast, pairs of liars thought of details that they were going to incorporate in their fabricated stories and to make sure that their fabricated stories matched one another. In other words, liars were preparing their answers to possible questions. They further decided not to give too much detail because providing details increases the chance of contradicting each other or of saying something that the interviewer knows to be untrue. After the interview liars were concerned that they had contradicted their partner during the interview.
The result of these different verbal strategies is that truth tellers' stories are likely to be more detailed than liars' stories, but that pairs of truth tellers are not necessarily more consistent than pairs of liars. Research has supported these two claims. Dozens of studies have shown that truthful stories tend to be more detailed than deceptive stories (see Vrij, 2008a, for a review); and Vrij et al. (2009) have shown that liars are equally consistent as truth tellers in their answers, at least when answering questions that they have anticipated. The findings therefore clearly demonstrate the hazards of interpreting consistencies as truthful and inconsistencies as deceptive, something lie detectors typically do ((Strömwall, Granhag, \& Hartwig, 2004; The Global Deception Team, 2006; Vrij, 2008a; Vrij, Akehurst, Knight, 2006). If lie detectors would consider more the verbal strategies used by truth tellers and liars, they may be less inclined to do so when interpreting answers to questions that the interviewees in all likelihood have anticipated.

Although truth tellers and liars did employ different verbal strategies, they used the same nonverbal strategies. Both truth tellers and liars believed that signs of nervousness would appear suspicious. They therefore decided that they would try to suppress displaying signs of nervousness during the interview. After the interview both truth tellers and liars were concerned that some signs of nervousness have given their lies away during the interview. The only difference in nonverbal strategies is that liars were more ready to employ them than truth tellers. Liars' stronger tendency to suppress signs of nervousness than truth tellers can, in part, explain why liars often display fewer movements than truth tellers (Vrij, 2008a), even in high stakes situations, such as police interviews (Mann, Vrij, \& Bull, 2002). Moving about makes a suspicious impression on observers (Strömwall, Granhag, \& Hartwig, 2004; The Global Deception Team, 2006; Vrij, 2008a; Vrij, Akehurst, Knight, 2006). Therefore, liars in particular attempt to avoid displaying such movements, resulting in displaying a more rigid demeanour than truth tellers. We believe that, if lie detectors would take more into account the nonverbal strategies used by truth tellers and liars, they will be less inclined to think that liars make more movements than truth tellers, and would understand better why the opposite pattern often occurs.

The fact that truth tellers and liars employ different verbal strategies but the same nonverbal strategies may explain, in part, why verbal cues to deceit are often more diagnostic than nonverbal cues to deceit (Vrij, 2008a, b). When truth tellers and liars employ different strategies to appear credible (as they do with verbal strategies) distinguishable differences are more likely to occur between truth tellers and liars than when they employ the same strategy (as they do with nonverbal strategies).

We believe that our findings provide a valuable tool for investigators how to conduct their interviews. We recommend the use of asking a mixture of questions that liars in all likelihood have anticipated and questions that they in all likelihood have not anticipated. When pairs of individuals decide to collude to make up a story, they discuss with each other what they are going to say. Interviewers should interview the two individuals separately but should ask them the same questions. When the interviewer starts by 
asking typical opening questions that pairs of liars are likely to have anticipated, liars are likely to provide similar answers in their individual, separate, interviews. After asking such opening questions, the interviewer should move on to asking questions that the liars in all likelihood will not have anticipated. The answers the pairs of liars give to these unanticipated questions are likely to show less overlap than the answers they gave to the anticipated questions. In contrast, for truth tellers it does not make much difference which questions are asked, as they can rely on their memory to answer each question. As a result, pairs of truth tellers will show a similar amount of overlap in their answers to anticipated and unanticipated questions. Therefore, a decrease in correspondence between answering the unanticipated questions compared to the anticipated questions can be expected to occur in pairs of liars but not in pairs of truth tellers.

\section{REFERENCES}

Colwell, K., Hiscock, C. K., \& Memon, A. (2002). Interview techniques and the assessment of statement credibility. Applied Cognitive Psychology, 16, 287-300.

Colwell, K., Hiscock-Anisman, C., Memon, A., Woods, D., \& Michlik, P. M. (2006). Strategies of impression management among deceivers and truth tellers: How liars attempt to convince. Amercian Journal of Forensic Psychology, 24, 31-38.

DePaulo, B. M., Lindsay, J. L., Malone, B. E., Muhlenbruck, L., Charlton, K. \& Cooper, H. (2003). Cues to deception. Psychological Bulletin, 129, 74-118.

Gilovich, T., Savitsky, K., \& Medvec, V. H. (1998). The illusion of transparency: Biased assessments of others' ability to read one's emotional states. Journal of Personality and Social Psychology, 75, 332-346.

Granhag, P.A. \& Hartwig, M. (2008). A new theoretical perspective on deception detection: On the psychology of instrumental mindreading. Psychology, Crime \& Law, 14, 189-200.

Granhag, P. A., Strömwall, L. A. (2002). Repeated interrogations: Verbal and nonverbal cues to deception. Applied Cognitive Psychology, $16,243-257$.

Granhag, P. A., Strömwall, L. A. \& Hartwig, M. (2007). The SUE technique: The way to interview to detect deception. Forensic Update, 88, 25-29.

Granhag, P. A., Strömwall, L. A., \& Jonsson, A. C. (2003). Partners in crime: How liars in collusion betray themselves. Journal of Applied Social Psychology, 33, 848-868.
Hartwig, M., Granhag, P. A., Strömwall, L. (2007). Guilty and innocent suspects' strategies during interrogations. Psychology, Crime, \& Law, 13, 213-227.

Hartwig, M., Granhag, P. A., Strömwall, L., Wolf, A., Vrij, A., \& Roos af Hjelmsater, E. (2008). Interviewing to detect deception: Eliciting cues to deception via strategic use of evidence. Manuscript submitted for publication.

Kassin, S. M. (2005). On the psychology of confessions: Does innocence put innocents at risk? American Psychologist, 60, 215-228.

Mann, S., Vrij, A., \& Bull, R. (2002). Suspects, lies and videotape: An analysis of authentic high-stakes liars. Law and Human Behavior, $26,365-376$

Strömwall. L. A., Granhag, P. A., \& Hartwig, M. (2004). Practitioners' beliefs about deception. In P. A. Granhag \& L. A. Strömwall (Eds.), Deception detection in forensic contexts (pp. 229-250). Cambridge, England: Cambridge University Press.

Strömwall, L. A, Granhag, P. A., \& Landström, S. (2007). Children's prepared and unprepared lies: Can adults see through their strategies? Applied Cognitive Psychology, 21, 457-471.

Strömwall, L. A., Hartwig, M., \& Granhag, P. A. (2006). To act truthfully: Nonverbal behaviour and strategies during a police interrogation. Psychology, Crime, \& Law, 12, 207-219.

The Global Deception Team (2006). A world of lies. Journal of CrossCultural Psychology, 37, 60-74.

Vrij, A. (2008a). Detecting lies and deceit: Pitfalls and opportunities, $2^{\text {nd }}$ ed. Chichester: John Wiley and Sons.

Vrij, A. (2008b). Nonverbal dominance versus verbal accuracy in lie detection: A plea to change police practice. Criminal Justice and Behavior, 35, 1323-1336.

Vrij, A., Akehurst, L., \& Knight, S. (2006). Police officers', social workers', teachers' and the general public's beliefs about deception in children, adolescents and adults. Legal and Criminological Psychology, 11, 297-312.

Vrij, A., Fisher, R., Mann, S., \& Leal, S. (2006). Detecting deception by manipulating cognitive load. Trends in Cognitive Sciences, 10, 4, 141-142.

Vrij, A., Fisher, R. P., Mann, S., \& Leal, S. (2008). A cognitive load approach to lie detection. Journal of Investigative Psychology and Offender Profiling, 5, 39-43.

Vrij, A., Fisher, R., Mann, S., \& Leal, S. (2009). Increasing cognitive load in interviews to detect deceit. (Invited chapter). In B. Milne, S. Savage, \& T. Williamson (Eds.), International developments in investigative interviewing (pp. 176-189). Uffculme: Willan Publishing.

Vrij, A., Leal, S., Granhag, P. A., Mann, S., Fisher, R. P., Hillman, J., \& Sperry, K. (2009). Outsmarting the liars: The benefit of asking unanticipated questions. Law and Human Behavior, 33, 159-166. 